\title{
PEMBELAJARAN AGAMA ISLAM PADA PROGRAM PPL DI SMPN 3 SAMBAS PADA MASA PANDEMI COVID-19
}

\author{
Muhammad Asyura \\ Institut Agama Islam Sultan Muhammad Syafiuddin Sambas \\ Corresponding Author: muhammadasyuramuhammad@gmail.com
}

\author{
Askamila \\ Institut Agama Islam Sultan Muhammad Syafiuddin Sambas \\ e-mail: askamilaiais@gmail.com \\ Shopia \\ Institut Agama Islam Sultan Muhammad Syafiuddin Sambas \\ e-mail: shopia.pia76@yahoo.com
}

\begin{abstract}
The Field Experience Practice Program (PPL) is a mandatory program implemented by students in the Islamic Religious Education (PAI) study program. The implementation of the PPL program during the Covid-19 pandemic underwent many adjustments including the PPL program in SMPN 3 Sambas in the 2021/2022. This research is a qualitative research to describe the implementation of learning and management of PPL programs in SMPN 3 Sambas during the Covid-19 pandemic. The data sources in this study are five PPL IAIS Sambas teachers, one Islamic teacher, and the principal. The data on this study is in the form of interview results and documentation of the program. The results showed that the PPL program at SMPN 3 Sambas school year 2021/2022 was carried out online and offline. The PPL program is held for two months in early July to early September 2021. In the first month, the implementation of PPL is carried out online and PPL teachers have not been directly involved but carry out micro teaching guided by teachers. In the first month, PPL teachers conduct online learning through WhatsApp groups and Google Meet. In the second month, learning was carried out offline because Covid-19 cases in Sambas Regency had decreased so that learning was implemented with an allocation of $50 \%$ of the number of students perelas by complying with health protocols. The findings in this study show that PPL programs with offline learning are much better organized than online because of the limitations of e-learning for both teachers and students. The presence of PPL teachers also has a positive impact with their learning innovations.
\end{abstract}

Keywords: Field Experience Practices (PPL), the Islamic Religious Education learning, Covid-19 pandemic 


\section{ABSTRAK}

Program Praktik Pengalaman Lapangan (PPL) adalah program wajib yang dilaksanakan oleh mahasiswa pada program studi Pendidikann Agama Islam (PAI). Pelaksanaan program PPL pada masa pandemi Covid-19 mengalami banyak penyesuaian termasuk program PPL di SMPN 3 Sambas tahun ajaran 2021/2022. Penelitian ini merupakan penelitian kualitatif yang bertujuan untuk mendeskripsikan pelaksanaan pembelajaran dan pengelolaan program PPL di SMPN 3 Sambas pada masa pandemi Covid-19. Sumber data pada penelitian ini adalah lima orang guru PPL IAIS Sambas, satu orang guru pamong, dan kepala sekolah. Data pada penelitian ini berupa hasil wawancara dan dokumentasi program tersebut. Hasil penelitian menunjukkan bahwa program PPL di SMPN 3 Sambas tahun ajaran 2021/2022 dilaksanakan secara daring dan luring. Program PPL diselenggarakan selama dua bulan pada awal Juli hingga awal September 2021. Pada bulan pertama, pelaksanaan PPL dilaksanakan secara daring dan guru PPL belum dilibatkan secara langsung namun melaksanakan micro teaching yang dibimbing guru pamong. Pada bulan pertama, guru PPL melaksanakan pembelajaran daring yang melalui grup WhatsApp dan Google Meet. Pada bulan kedua, pembelajaran dilaksanakan secara luring karena kasus Covid-19 di Kabupaten Sambas telah menurun sehingga pembelajaran dilaksanakan dengan alokasi 50\% jumlah siswa perkelas dengan mematuhi protokol kesehatan. Hasil temuan dalam penelitian ini menunjukkan bahwa program PPL dengan pembelajaran luring jauh lebih baik diselenggarakan daripada daring karena keterbatasan penguasaan penggunaan e-learning baik bagi guru maupun murid. Kehadiran guru PPL juga memberikan dampak positif dengan inovasi pembelajarannya.

Kata Kunci: Praktik Pengalaman Lapangan (PPL), pembelajaran PAI, pandemi Covid-19

\section{PENDAHULUAN}

Praktik Pengalaman Lapangan (PPL) adalah program pelatihan calon guru yang dirangkai khusus untuk mahasiswa di kampus LPTK yang dipraktikkan di sekolah mitra. Program PPL diselenggarakan agar mahasiswa dapat mempraktikkan teori yang diperoleh selama kuliah sehingga memperoleh keterampilan khusus sesuai dengan keahlian dalam profesi keguruan (Adi, 2015). Dengan kata lain, program PPL memberikan kesempatan kepada mahasiswa untuk menunjukkan semua kompetensi yang telah dimiliki di bawah arahan guru pamong dan dosen pembimbing.

Program PPL merupakan program yang wajib diikuti mahasiswa Program Studi Pendidikan Agama Islam (PAI), Fakultas Tarbiyah dan Ilmu Keguruan (FTIK), Institut Agama Islam Sultan Muhammad Syafiuddin (IAIS) Sambas. Saat mengikuti program PPL, mahasiswa Prodi PAI FTIK IAIS Sambas diberikan kesempatan untuk mengenal administrasi di sekolah dan mempraktikkan teori pembelajaran yang diperoleh di kampus kepada siswa di sekolah. Kegiatan ini dilaksanakan selama tiga bulan dengan sistem magang terbimbing.

Pembinaan mahasiswa PPL Prodi PAI FTIK IAIS Sambas di sekolah mitra dilaksanakan oleh dosen pembimbing yang kompeten yang dibantu 
oleh guru pamong selaku eksekutor, dan kepala sekolah selaku regulator. Guru pamong dipilih dan ditugaskan oleh kepala sekolah mitra secara teknis akan berkoordinasi wakil kepala sekolah bidang kurikulum untuk mendiskusikan sistem PPL bersama dosen pembimbing. Hal ini akan menunjang maksimalnya program PPL tersebut.

Dalam Buku Pedoman Pelaksanaan PPL IAIS Sambas 2021 disebutkan bahwa tugas atau tanggung jawab dosen pembimbing dan guru pamong adalah membimbing mahasiswa dalam melaksanakan PPL, mendiskusikan berbagai masalah yang dijumpai mahasiswa di lapangan, dan mengarahkan mahasiswa untuk berburu berbagai pengalaman yang dapat dijadikan bekal sebagai calon guru yang profesional. Dalam kegiatan kesehariannya, proses pembimbingan lebih banyak dilakukan oleh guru pamong sedangkan dosen pembimbing dengan pertimbangan kesibukan di kampus, diwajibkan melaksanakan bimbingan atau hadir ke sekolah mitra minimal 4 kali, yaitu pada awal, pertengahan, menjelang mahasiswa mengikuti ujian PPL, dan saat mahasiswa mengikuti ujian PPL.

Semenjak adanya instruksi dari Kemendikbud untuk melaksanakan pembelajaran daring pada wilayah terdampak Covid-19, sejak itupula semua sekolah memberhentikan pembelajaran tatap muka. Instruksi tersebut memaksa semua lembaga pendidikan termasuk sekolah untuk mengubah teknis pembelajaran. Hal tersebut juga berdampak pada seluruh kegiatan akademik seperti layanan administrasi hingga pelaksanaan program PPL tahun 2021.

Akibat wabah Covid-19, pembelajaran harus dilakukan secara daring (online). Pemerintah melarang lembaga pendidikan untuk melakukan pembelajaran secara langsung guna mencegah penularan. Kebijakan lockdown dan karantina mandiri juga digunakan untuk meminimalisasi penyebaran virus. Dampak pandemi pada pendidikan yaitu keharusan setiap tenaga pendidik dan peserta didik untuk mengetahui berjalannya pendidikan secara daring.

Berkaitan dengan hal tersebut, Prodi PAI yang akan melaksanakan Program PPL segera menentukan sikap dengan cara berkoordinasi dengan unit PPL IAIS Sambas membahas tentang pelaksanaan program PPL di masa pandemic ini. Hal ini penting mengingat Program PPL merupakan satu di antara mata kuliah wajib.

Program PPL mempunyai bobot 4 SKS dan ditempuh di semester ganjil yaitu semester 7 . Program PPL yang selama ini diselenggarakan oleh program studi PAI FTIK IAIS Sambas sangat berbeda dengan pelaksanaan Program PPL di tahun sebelumnya. Pelaksanaan PPL tahun 2021 ini harus menyesuaikan dengan otoritas sekolah mitra yang didasari pada instruksi Pemda Sambas dengan melaksanakan pembelajaran daring maupun pembelajaran tatap muka secara terbatas. Dengan pelaksanaan yang berbeda tersebut, maka dibutuhkan model penyelenggaraan program PPL yang efektif guna mendapatkan hasil yang maksimal.

Pada penelitian ini, peneliti mengumpulkan berbagai data terkait pelaksanaan Program PPL di SMPN 3 Sambas sebagai satu di antara sekolah sasaran. Hal ini dapat memberikan gambaran secara umum bagaimana pelaksanaan program PPL yang dilaksanakan oleh mahasiswa Prodi PAI FTIK IAIS Sambas, sistem pembelajaran selama program PPL berlangsung, 
dan hasil umum pembelajaran PPL selama pandemi Covid-19 di Kabupaten Sambas. Dengan paparan tersebut, maka peneliti menulis penelitian ini untuk dijadikan referensi pelaksanaan Program PPL selama pandemik Covid-19.

\section{METODE PENELITIAN}

Penelitian ini merupakan penelitian kualitatif yang bertujuan untuk mendeskripsikan program Praktik Pengalaman Lapangan (PPL) oleh mahasiswa Pendidikan Agama Islam (PAI) Fakultas Tarbiyah dan Ilmu Keguruan (FTIK) Institut Agama Islam Sultan Miuhammad Syafiuddin (IAIS) Sambas di SMPN 3 Sambas selama pandemi Covid-19. Penelitian ini masuk dalam jenis penelitian lapangan untuk mendeskripsikan dan memahami fenomena yang dialami oleh subjek penelitian (guru, kepala sekolah, dan murid) selama program PPL di SMPN 3 Sambas saat pandemi Covid-19.

Subjek penelitian ini adalah mahasiswa PPL Prodi PAI FTIK IAIS Sambas, kepala sekolah, guru pamong, dan siswa di SMPN 3 Sambas. Subjek penelitian tersebut ditentukan secara purposive sesuai kebutuhan pengumpulan data dan konteks permasalahan yang diangkat.

Penelitian ini dilakukan pada semester ganap tahun akademik 2020/2021 selama pelaksanaan Program PPL di SMPN 3 Sambas. Pada masa pandemi Covid-19, Program PPL tersebut dilaksanakan selama dua bulan. Pada bulan pertama dijalankan pembelajaran daring (online) sedangkan pada bulan berikutnya pembelajaran dilaksanakan secara tatap muka parsial dengan protokol kesehatan yang ketat karena kasus Covid-19 di Kabupaten Sambas berangsur menurun.

Penelitian ini melibatkan dua variabel deskriptif dengan definisi operasional sebagai berikut. (1) pembelajaran agama Islam merujuk pada program pembelajaran pada Mata Pelajaran Agama Islam yang diselenggarakan oleh sekolah yang dalam hal ini adalah SMPN 3 Sambas. Pada konteks penelitian ini dipersempit yaitu pembelajaran Agama Islam selama pandemi Covid-19 (2) Program program Praktik Pengalaman Lapangan (PPL) merujuk pada kesiapan mahasiswa dan sistem pelaksanaan PPL di SMPN 3 Sambas selama pandemi Covid-19. Data dalam penelitian ini dikumpulkan dengan metode wawancara dan pengisian angket. Agar keabsahan data lebih meyakinkan melalui angket, maka pengumpulan data dilengkapi dengan wawancara terbimbing. Penyebaran angket dan wawancara dilaksanakan oleh tim peneliti. Pengambilan data dilaksanakan pada saat pelaksanaan PPL di SMPN 3 Sambas selama pandemi Covid-19.

Data yang sudah didapatkan dari hasil observasi, wawancara, dan dokumentasi maka data-data tersebut dianalisis dengan teknik keabsahan data menggunakan tringulasi dan kecukupan data serta ketekunan peneliti. Sedangkan untuk menganalisis data dilakukan dengan analisis deskriptif kualitatif. Analisis data dilakukan dengan langkah-langkah pengumpulan data, sajian data, reduksi data, dan penarikan simpulan. Analisis data tersebut diringkas menjadi tiga tahap yaitu yaitu reduksi data, penyajian data, dan verifikasi hasil penelitian hingga penarikan simpulan (Mills dan Hubarman, 2005).

Adapun teknik analisis data penelitian yang akan dilakukan dalam penelitian tindakan kelas ini, sebagai berikut. 
a. Peneliti mengumpulkan data penelitian dari hasil observasi pelaksanaan pembelajaran agama Islam oleh guru PPL, guru pamong, kepala sekolah, dan siswa selama proses pembelajaran pandemi Covid-19 di SMPN 3 Sambas.

b. Peneliti mengumpulkan data hasil wawancara pelaksanaan pembelajaran agama Islam pada guru PPL, guru pamong, kepala sekolah, dan siswa selama proses pembelajaran pandemi Covid-19 di SMPN 3 Sambas.

c. Peneliti mengumpulkan data hasil dokumentasi pelaksanaan pembelajaran agama Islam pada guru PPL, guru pamong, kepala sekolah, dan siswa selama proses pembelajaran pandemi Covid-19 di SMPN 3 Sambas.

d. Peneliti mendeskripsikan sistem pembelajaran dan sistem pelaksanaan program Praktik Pengalaman Lapangan (PPL) secara umum yang diselenggarakan SMPN 3 Sambas selama pandemi Covid-19.

e. Peneliti mendeskripsikan pelaksanaan program Praktik Pengalaman Lapangan (PPL) dan pembelajaran agama Islam yang diselenggarakan SMPN 3 Sambas selama pandemi Covid-19.

f. Peneliti merumuskan simpulan penelitian terkait sistem pembelajaran dan sistem pelaksanaan program Praktik Pengalaman Lapangan (PPL) secara umum yang diselenggarakan SMPN 3 Sambas selama pandemi Covid-19.

\section{PEMBAHASAN}

\section{A. Deskripsi Umum Program PPL Institut Agama Islam Sultan Muhammad Syafiuddin (IAIS) Sambas di SMPN 3 Sambas}

Institut Agama Islam Sultan Muhammad Syafiuddin (IAIS) Sambas merupakan satu di antara perguruan tinggi di Kabupaten Sambas yang berperan penting dalam mencetak tenaga kependidikan yang profesional. Untuk dapat membekali mahasiswa dalam bidang kependidikan secara lebih nyata, dilaksanakanlah Praktik Pengalaman Lapangan (PPL) (Tim UPT PPL, 2021). Program PPL diharapkan dapat menjadi bekal bagi mahasiswa Fakultas Tarbiyah dan Ilmu Keguruan (FTIK) IAIS Sambas sebagai wahana pembentukan tenaga kependidikan yang memiliki empat kompetensi yaitu pedagogik, kepribadian, sosial, dan profesional. Hal ini dilakukan untuk mencetak guru yang siap memasuki dunia pendidikan yang memiliki sikap, nilai, pengetahuan, dan keterampilan profesional.

Program PPL berorientasi pada kompetensi pendidikan, pembentukan profesionalisme guru, dan tata kelola administrasi sekolah secara terbimbing dan terpadu (Hamalik dalam Mubarok, 2020). Orientasi tersebut bertujuan untuk melatih calon guru yang berkepribadian dan berpengetahuan yang mumpuni untuk mendukung menyelenggarakan pendidikan bermutu.

Berkaitan dengan hal tersebut, maka Unit Praktik Pengalaman Lapangan (UPPL) FTIK IAIS Sambas berusaha meningkatkan kualitas calon pendidik dengan melaksanakan PPL di berbagai sekolah di Kabupaten Sambas. Satu di antara sekolah mitra tempat dilaksanakannya program PPL yaitu di SMPN 3 Sambas. Mahasiswa dapat memperoleh pengalaman dalam bidang kependidikan dan diharapkan dapat memberikan bantuan 
pemikiran, tenaga, dan ilmu pengetahuan pada pembelajaran di sekolah tersebut.

SMPN 3 Sambas (NPSN 30100292) merupakan Sekolah Menengah Pertama Negeri (SMPN) yang berlokasi di Jalan Pendidikan No. 278, Desa Jagur, Kecamatan Sambas, Kabupaten Sambas, Provinsi Kalimantan Barat. Sekolah ini berada di pusat kota dan kawasan pendidikan Sambas yang strategis.

Pada program PPL semester genap tahun ajaran 2021/2022 di SMPN 3 Sambas ini, unit PPL FTIK IAIS Sambas menugaskan Muhammad Asyura, M.Pd. untuk menjadi dosen pembimbing untuk lima orang mahasiswa di Program Studi Pendidikan Agama Islam (PAI). Nama-nama mahasiswa tersebut antara lain Askamila (NIM101.2018.004), Fitrie Aulia Meliny Nasution (NIM 101.2018.010), Hera Witriana (NIM 101.2018.012), Lulu Noflya (NIM 101.2018.016), dan Shopia (NIM 101.2018.027).

Selama pandemi Covid-19, pelaksanaan Program PPL ini dikurangi menjadi dua bulan yang seharusnya dilaksanakan selama tiga bulan. Program PPL di SMPN 3 Sambas tersebut dilaksanakan pada 12 Juli 2021 hingga 18 September 2021. Pada bulan pertama proses pelaksanaan PPL, mahasiswa PPL hanya dapat melaksanakan praktik belajar secara daring dan terbatas. Praktik mengajar lebih banyak dilakukan secara internal dengan sistem mentoring teman sejawat (microteaching). Hal ini dilakukan karena kasus penularan Covid-19 di Kabupaten Sambas masih cukup tinggi. Namun, pada bulan kedua (akhir Agustus hingga awal September), pembelajaran sudah diizinkan dengan tatap muka terbatas oleh Pemerintah Daerah Kabupaten Sambas. Kelima mahasiswa PAI tersebut dapat melaksanakan PPL dengan baik. Hal ini memberikan keuntungan ganda karena kelima mahasiswa PAI IAIS Sambas tersebut mendapatkan pengalaman pembelajaran secara daring dan tatap muka meskipun secara terbatas (parsial).

Program PPL ini tidak akan berjalan lancar tanpa bantuan guru pamong yaitu Leo Hardi, S.Pd. yang mengampu mata pelajaran Agama Islam. Kegiatan tersebut juga tentunya mendapat dukungan penuh oleh Dra. Tetty Tatiana Kusumarini selaku Kepala Sekolah SMPN 3 Sambas. Bimbingan dan arahan dari guru lain pun mengalir untuk kelima mahasiswa PAI sehingga mereka mampu memahami dan melaksanakan praktik mengajar secara langsung seperti layaknya seorang tenaga pendidik yang baik. Hal ini juga dilakukan dengan mempertimbangkan instruksi Pemda Sambas dengan melaksanakan protokol kesehatan yang ketat selama masa pandemi Covid-19

\section{B. Deskripsi Khusus Sistem dan Hasil Pembelajaran pada Mata Pelajaran Agama Islam selama Pandemi Covid-19 pada Program PPL di SMPN 3 Sambas}

Guru Pendidikan Agama Islam (PAI) sebagai tenaga pendidik, baik masih berstatus sebagai mahasisiwa PPL ataupun guru profesi, memiliki peran penting dalam menyampaikan ilmu tidak ubahnya sebagai pendakwah. Pemahaman terhadap pengelolaan pembelajaran merupakan hal mutlak yang harus dikuasai guru agama Islam (Choeroni, dkk, 2013:2). Mereka tentunya menjadi tonggak utama dalam penanaman karakter umat 
terutama siswa sebagai generasi muda. Hal ini seperti dalam firman Allah Swt QS.Mujadillah (58) ayat 11 yang menjelaskan tentang keutamaan seorang guru dalam keilmuannya yang artinya:

\begin{abstract}
"Wahai orang-orang yang beriman! Apabila dikatakan kepadamu, "Berilah kelapangan di dalam majelis-majelis," maka lapangkanlah, niscaya Allah akan memberi kelapangan untukmu. Dan apabila dikatakan, "Berdirilah kamu," maka berdirilah, niscaya Allah akan mengangkat (derajat) orang-orang yang beriman di antaramu dan orang-orang yang diberi ilmu beberapa derajat. Dan Allah Mahateliti apa yang kamu kerjakan"
\end{abstract}

Saat berjalannya proses pembelajaran selama pandemi Covid-19 pada Awal Juli hingga pertengahan Agustus, guru PAI di SMPN 3 Sambas melakukan pembelajaran dari secara terbatas. Sekolah harus patuh dengan kebijakan pembelajaran daring oleh pemerintah. Hal ini menurut Simanjuntak dkk. (2020) dilakukan sebagai suatu langkah untuk memutus rantai penyebaran virus corona. Namun, hal ini membuat dunia Pendidikan melakukan banyak penyesuaian pembelajaran sehingga muncul masalah baru. Pandemi Covid-19 juga menimbulkan dampak jangka pendek pada keberlangsungan pembelajaran yang dirasakan oleh dunia pendidikan di desa maupun di kota karena masih asing dengan pembelajaran daring. Guru masih belum bisa mengaplikasikan berbagai media daring secara maksimal mengingat keterbatasan sumber daya, fasilitas, maupun kemampuan siswa dalam menggunakan berbagai platform kekinian.

Menurut Julianti (2021), kendala lain pada pelaksanaan pembelajaran daring yaitu adanya beberapa materi dan praktik peribadatan yang harus dilakukan melalui sistem singkronus (daring secara langsung) maupun nonsingkronus (daring secara tidak langsung lewat tayangan). Penggunaan aplikasi seperti WhatsApp Group, Google Meet, dan Google Classroom dengan dua sistem tersebut masih belum maksimal jika diaplikasikan di Kabupaten Sambas. Tidak sedikit siswa yang tinggal di berbagai kecamatan pelosok Kabupaten Sambas yang mengalami kesulitan sinyal untuk mengakses internet. Selain itu, menurut Ulya (2021) kurangnya interaksi dengan pendidik dan praktik keagamaan pada pelajaran PAI berpotensi menurunnya budi pekerti serta moralitas peserta didik. Hal ini juga diperburuk dengan kemampuan orang tua siswa untuk menyediakan gawai dan media belajar yang mumpuni sehingga pertimbangan guru dalam pemilihan platform dan sistem apa yang cocok untuk pembelajaran pada masa pandemi semakin sulit.

"Saya merasa sulit belajar karena HP milik orang tua. Kadang memorinya penuh jadi susah untuk memakai Google Classroom. Saya lebih senang menggunakan grup WA saja ketika guru memberikan tugas dan mengumpulkan tugasnya," tutur Andri Mushari siswa kelas 2A SMPN 3 Sambas (5 Agustus 2021). 
Selain itu, banyak guru merasa gagap menghadapi perubahan pembelajaran secara drastis karena belum menguasai sistem pembelajaran daring (Aprila dan Muliati, 2021). Bukan hanya itu, terkendalanya akses internet yang kurang memadai memicu guru dan siswa mengalami kesulitan sehingga pembelajaran sebatas dilakukan lewat media sosial dan hanya sesekali melibatkan e-learning. Hal ini juga didukung dengan penelitian Ratnawati dan Utama (2021), bahwa tidak jarang pelajar harus datang ke café untuk mendapatkan sinyal wifi di tengah pandemi sehingga mengancam kesehatan. Tujuan pembelajaran daring untuk mengurangi kerumunan masal pun gagal. Alhasil, guru banyak menggunakan medsos seperti WhatsApp grup dalam proses pembelajaran.

"Kebanyakan guru kami menggunakan grup WA yang dianggap lebih mudah digunakan walau dengan jaringan internet yang minim," tutur Tetty Tatiana Kusumarini, Kepala Sekolah SMPN 3 Sambas (25 Juli 2021).

Hasil wawancara tersebut diperkuat dengan data pengisian angket sederhana pada sampel beberapa siswa kelas VII setelah proses pembelajaran materi Birrul Walidain (Berbakti kepada Orang Tua). Pemahaman siswa terhadap materi tersebut dengan penyampaian secara daring lewat grup WA cenderung tidak mendapatkan tanggapan yang positif. Para siswa rata-rata menjawab pertanyaan sesuai angket pada penilaian atau angka terendah pada rentang 2 hingga 3 dari skala 1-5. Pada angket, tidak seorang pun yang memilih jawaban "sangat setuju" atau poin 5 pada pembelajaran tentang Birrul Walidain (Berbakti kepada Orang Tua) yang telah berlangsung. Pembelajaran tersebut dilaksanakan oleh guru PAI di SMPN 3 Sambas yang belum melibatkan peran serta guru PPL PAI IAIS Sambas.

Pada Akhir Agustus, ketika pembelajaran tatap muka dilaksanakan secara terbatas, guru PPL mulai dilibatkan secara langsung dalam pembelajaran tatap muka tersebut. Satu di antara guru PPL, Askamila, diizinkan untuk melaksanakan pembelajaran dengan materi taharah pada siswa kelas VII A gelombang pertama dengan metode demonstrasi. Tingkat pemahaman siswa terhadap materi taharah dengan metode demonstrasi tergambar jelas lewat evaluasi pembelajaran serta tanggapan positif dari siswa. Pada akhirnya siswa dapat memahami materi taharah yang diajarkan dengan baik dan sistimatis oleh kolaborasi guru PAI dan guru PPL.

Simpulan pertama dari sudut pandang siswa berdasarkan hasil wawancara dan pengisian angket menunjukkan bahwa penggunaan metode demonstrasi telah memberikan semangat dan meningkatkan minat belajar siswa. Mereka dapat dengan mudah memahami dan menerima materi yang disampaikan oleh guru. Kegiatan pembelajaran akan menjadi menarik jika metode pembelajaran serta mempraktikkannya dengan benar. Metode demonstrasi yang dipadukan dengan metode konvensional yang biasa digunakan oleh guru PAI SMPN 3 Sambas (metode ceramah, tanya jawab, dan penugasan) memberikan dampak positif oleh siswa. 
Hal tersebut sejalan dengan hasil wawancara mendalam kepada guru PAI SMPN 3 Sambas. Menurut Hardi (20 Agustus 2021):

"Kehadiran lima orang guru PPL asal IAIS ini sangat membantu saya dalam memberikan inovasi kecil yang berdampak besar. Pembelajaran daring yang telah berlangsung lebih dari satu tahun belakangan ini telah mematikan kreatifitas kami para guru di Kabupaten Sambas yang masih ketinggalan terkait literasi digital maupun terkait penyesuaian metode pembelajaran yang cocok"

Saat guru PPL hadir dan pembelajaran tatap muka terbatas diberlakukan, guru PAI dan guru PPL berkolaborasi dengan baik untuk merancang pembelajaran yang efektif dan lebih bermakna. Satu di antaranya adalah penerapan metode demonstrasi yang diaplikasikan pada materi taharah tersebut. Berdasarkan hasil observasi guru terjadi perbedaan yang signifikan antara pembelajaran daring dan tatap muka dengan meteri yang sama pada metode yang berbeda. Menurut Hardi (5 Agustus 2021):

"Siswa lebih interaktif dan lebih mudah memahami materi dan tidak sungkan untuk mempraktikkan beberapa cara bersuci di musala sekolah. Mereka merasa adanya kebersamaan sehingga mereka berani tampil dan mendemostrasikan sesuai teori yang telah disampaikan guru. Siswa pun dapat menjawab soal teoretis dengan benar dengan nilai yang memuaskan. Proses pembelajaran berjalan dengan baik dan efektif walau dengan pembatasan waktu belajar dan protokol kesehatan yang ketat"

Hal ini ternyata amat berbeda saat siswa pada tahun ajaran lalu yang belajar dengan materi yang sama secara daring. Siswa cenderung monoton pada ceramah guru PAI dan cenderung mengalami kebosanan ditambah lagi dengan kewajiban mengerjakan berbagai tugas yang harus dikumpulkan sebagai tolok ukur terjadinya pembelajaran. Hal ini sejalan dengan pendapat kepala sekolah SMPN 3 Sambas, Kusumarini (28 Juli 2021):

"Pembelajaran daring yang telah berlangsung lebih dari satu tahun ini membuat kami, para guru, segera berbenah. Banyak guru yang masih belum bisa menyesuaikan pembelajaran baru secara daring sehingga membutuhkan adaptasi yang cukup lama untuk menyiapkan pembelajaran. Siswa dan orang tua siswa pun merasa keberatan dengan pembelajaran daring yang dirasa kurang efektif mengingat penggunaan metode yang belum maksimal, biaya kuota yang besar, dan menumpuknya tugas siswa selama sekolah."

Setelah pembelajaran tatap muka terbatas diberlakukan sesuai anjuran Pemerintah Kabupaten Sambas, pembelajaran mulai berangsur kondusif. Guru mulai berbenah Kembali untuk menyesuaikan diri Kembali terlebih 
kedatangan guru PPL yang satu di antaranya dari jurusan PAI. Berikut cuplikan hasil wawancara dengan kepala sekolah SMPN 3 Sambas, Kusumarini (28 Juli 2021) tentang peran guru PPL dan efektivitas penggunaan metode demonstrasi yang diterapkan:

"Kedatangan guru-guru PPL jurusan PAI ini memberikan warna baru dan motivasi bagi guru di sekolah kami. Guru muda yang berbakat dari IAIS Sambas telah membantu guru PAI dalam berkolaborasi membuat pembelajaran menjadi lebih baik. Misalnya, saat saya lihat sekilas para siswa mempraktikan cara berwudu di musala sekolah. Saya lihat amat antusias dan menyenangkan"

Metode demonstrasi yang digunakan telah memegang peranan penting dalam mendukung kegiatan belajar mengajar pada siswa kelas VII SMPN 3 Sambas. Penggunaan metode terssebut amat tepat dan efektif untuk mencapai kompetensi dasar materi taharah. Hal ini sejalan dengan cuplikan wawancara tambahan dengan kepala sekolah SMPN 3 Sambas, Kusumarini (28 Juli 2021) sebagai berikut:

"Saya cek hasil evaluasi belajar siswa khususnya pada materi taharah berdasarkan rekapan nilai dari guru PAI menunjukkan hasil yang memuaskan. Hal ini juga dapat dilihat dari antusiasme siswa saat belajar walau hanya sekilas saya amati. Harapan saya, pelajaran seperti ini dapat berlangsung terus menerus tentunya dengan menyesuaikan metode pembelajaran yang tepat. Tapi menurut saya metode demonstrasi yang digunakan tersebut sudah berhasil meningkatkan minat belajar siswa."

Berdasarkan hasil evaluasi belajar siswa, wawancara mendalam dengan siswa, guru PAI, dan kepala sekolah SMPN 3 Sambas, maka dapat disimpulkan bahwa program PPL di SMPN 3 Sambas yang dilaksanakan oleh mahasiswa PAI FTIK IAIS Sambas berjalan dengan lancar. Peran guru PPL dalam pembelajaran memberikan warna baru dalam meningkatkan proses pembelajaran terutama saat pembelajaran tatap muka terbatas atau parsial dilaksanakan. Pembelajaran daring sudah ditinggalkan mengingat kondisi kasus Covid-19 di Kabupaten Sambas berangsur menurun walau dengan protokol kesehatan yang sangat ketat. Melalui program PPL tersebut, upaya peningkatan kompetensi mengajar guru maupun calon guru sebagaimana disyaratkan dalam Undang-undang Sistem Pendidikan Nasional No.20 Tahun 2003 yang terdiri atas kompetensi, profesional, kompetensi, pedagogis, kompetensi sosial, dan kompetensi personal dapat terwujud. Diharapkan program PPL tetap berlanjut dengan kemitraan yang terjalin lebih baik lagi.

Hasil temuan akhir pada penelitian ini adalah program PPL dengan pelaksanaan pembelajaran secara luring jauh lebih efektif daripada daring. Hal ini dilatarbelakangi dengan kesiapan guru dan siswa dalam menggunakan e-learning yang kurang mumpuni. Banyak pilihan e-lerning 
namun nyatanya guru dan murid hanya menggunakan media sosial seperti Whatsapp group dan sesekali menggunakan Google Classroom serta mengumpulkan tugas secara manual ke sekolah. Hal ini membuat proses dan hasil belajar daring kurang maksimal yang jauh berbeda dengan pembelajaran luring yang biasa dilaksanakan sebelum pandemi Covid-19.

Pembelajaran luring walau dilakukan secara terbatas dengan protokol kesehatan yang ketat memberikan dampak pembelajaran yang positif. Hal ini tampak jelas pada materi peribadatan yang harus dipraktikkan secara langsung terlebih mendapat bantuan dari guru PPL sebagai inovator pembelajaran PAI.

\section{PENUTUP}

Selama masa pandemi Covid-19, kegiatan pelayanan administrasi dan pembelajaran di SMPN 3 Sambas mengalami hambatan. Semua komponen pendukung sekolah harus berbenah dengan sistem pembelajaran dan administrasi daring. Hal ini juga terjadi pada program Praktik Pengalaman Lapangan (PPL) harus dirancang secara tepat guna.

Program PPL diselenggarakan selama dua bulan pada awal Juli hingga awal September 2021. Pada bulan pertama, pelaksanaan PPL dilaksanakan secara daring dan guru PPL belum dilibatkan secera langsung namun melaksanakan micro teaching yang dibimbing guru pamong dan dosen pembimbing. Pada bulan kedua, guru PPL melaksanakan pembelajaran daring dan luring yang disesuaikan dengan situasi dan kondisi. Pembelajaran daring dilaksanakan melalui grup WhatsApp dan Google Meet sedangkan secara luring dilaksanakan dengan tatap muka atau pertemuan parsial karena kasus Covid-19 di Kabupaten Sambas telah menurun. Berdasarkan penelitian ini, program PPL dengan pelaksanaan pembelajaran secara luring jauh lebih efektif daripada daring. Hal ini dilatarbelakangi dengan kesiapan guru dan siswa dalam menggunakan e-learning yang kurang mumpuni

Pemerintah melalui Dinas Pendidikan Kabupaten Sambas hendaklah lebih sigap dalam memberikan solusi pembelajaran selama pandemi Covid19. Hal tersebut dapat dilakukan dengan sosialisasi penggunaan e-learning, penyediaan jaringan internet pada daerah terluar, dan pemberian subsidi kuota belajar untuk siswa serta fasilitas penunjang lainnya. Hal tersebut akan terwujud jika terjalinnya kerja sama dan komitmen dari pemerintah dan masyarakat untuk meningkatkan mutu pendidikan di Kabupaten Sambas. 


\section{DAFTAR PUSTAKA}

Adi, I Putu Panca. (2015). SISTEM EVALUASI DAN KESIAPAN PELAKSANAAN PPL- REAL DI SEKOLAH MITRA (E-Jurnal) Jurnal Pendidikan Indonesia Vol. 4, No.2 H1m.657-665, Oktober 2015. https://ejournal.undiksha.ac.id.

Aprila, Dina dan Indah Muliati. (2021). DIAGNOSIS KESULITAN BELAJAR SISWA PADA MATA PELAJARAN PAI DI MASA PANDEMI COVID19 (E-Jurnal) Halaman 7196-7202 Jurnal Pendidikan Tambusai Volume 5 Nomor 3 Tahun 2021 https://Downloads/2113Article\%20Text-4218-1-10-20211029.pdf.

Choeroni, dkk. (2013). Pendidikan Agama Islam. Jakarta: Erlangga

Julianti, Siti Nur Halizah. (2021). DAMPAK PANDEMI COVID-19 PADA PROSES PEMBELAJARAN DARING PENDIDIKAN AGAMA ISLAM DI KELAS VIII SMP NEGERI 1 SUNGGUMINASA KABUPATEN GOWA (Skripsi) FTIK PAI Universitas Muhammadiyah Makassar https://Downloads/Skripsi\%20Dampak\%20Pandemi\%20pd\%20P AI\%20Daring.pdf

Miles, Matthew B. and A. Michael Huberman. (2005). Qualitative Data Analysis (terjemahan). Jakarta: UI Press.

Mubarok, Ramdanil. (2020) MODEL PENGELOLAAN PRAKTIK PENGALAMAN LAPANGAN PADA MASA PANDEMI (E-Jurnal) Journal of Islamic Education Management Oktober 2020, Vol.5, No.2 Hal 147-160. https://ejournal.iainpalopo.ac.id/index.php/kelola

Prawanti, Lia Titi dan Woro Sumarni. (2020). KENDALA PEMBELAJARAN DARING SELAMA PANDEMI COVID-19 (Prosiding) Seminar Nasional Pascasarja Unnes Semarang https://Downloads/603Article\%20Text-1544-1-10-20210216.pdf

Ratnawati, Etty dan Aditya Putra Utama. (2021). KESULITAN MAHASISWA DALAM PEMBELAJARAN DARING PADA MASA PANDEMI COVID-19 (e-jurnal) Jurnal Edueksos Vol. X, No. 1, Juni 2021 https / / Downloads /JURNAL\%20Kesulitan\%20Pem.\%20daring.pdf

Simanjuntak, Dosmika Ria dkk. (2020). ANALISIS KESULITAN BELAJAR SISWA MELAKSANAKAN PEMBELAJARAN SECARA DARING SELAMA MASA PANDEMI COVID-19 JURNAL MathEdu (Mathematic Education Journal) Vol. 3 No. 3 November 2020 http://journal.ipts.ac.id/index.php/MathEdu. 
Tim UPT PPL. 2021. Buku Pedoman Pelaksanaan PPL dan KKN FTIK IAIS Sambas. Sambas: IAIS Press.

Ulya, M. Abdul Wahid. (2021). PROBLEMATIKA PEMBELAJARAN PENDIDIKAN AGAMA ISLAM MELALUI MICROSOFT TEAMS PADA MASA PANDEMI (E-Jurnal) Jurnal Sains Sosio Humaniora Volume 5 Nomor 1 Juni 2021 https://Downloads/14135Article\%20Text-38672-1-10-20210719.pdf

Wawancara mendalam kepada Leo Hardi (Guru PAI SMPN 3 Sambas) pada 5 Agustus 2021.

Wawancara mendalam kepada Tetty Tatiana Kusumarini (Kepala Sekolah SMPN 3 Sambas) pada 28 Juli 2021. 